\title{
Incidence of umbilical cord around the neck and its effects on mode of delivery and fetal outcome at tertiary care hospital
}

\author{
S. Nandhini, C. R. Anuradha, S. Renuka*, K. Vijayalakshmi, R. Sailatha
}

Department of Obstetrics and Gynecology, Chettinad Hospital and Research Institute, Kelambakkam, Chennai, Tamil Nadu, India

Received: 09 December 2020

Accepted: 24 December 2020

*Correspondence:

Dr. S. Renuka,

E-mail: dralgates@gmail.com

Copyright: (C) the author(s), publisher and licensee Medip Academy. This is an open-access article distributed under the terms of the Creative Commons Attribution Non-Commercial License, which permits unrestricted non-commercial use, distribution, and reproduction in any medium, provided the original work is properly cited.

\begin{abstract}
Background: Umbilical cord is one of the fetal membranes. It is developed from the yolk sac. Umbilical cord is tubular structure. Approximate length of the cord is $50 \mathrm{~cm}$. Umbilical cord around the neck is called as the nuchal cord. The aim of the study is to find out the incidence of umbilical cord around the neck at the time of delivery and its fetal outcomes.

Methods: It is a retrospective observational study. This study was conducted in the department of obstetrics and gynecology at a tertiary care hospital over a period of 6 months (Feb-Jul 2020). Out of 542 patients, 388 were enrolled in this study after the inclusion and exclusion criteria, of which 101 were delivered with umbilical cord and the remaining were 287 patients in control group.

Results: Present study showed 38.4\% incidence of umbilical cord at the time of delivery. Incidence is more among the primigravida and it is statistically significant. Both intrapartum and postpartum risks are not related to umbilical cord around the neck. Mean length of the cord in patients delivered with cord around the neck is more when compared to the control group and has significant $\mathrm{p}$ value.

Conclusions: This study concludes that the presence of umbilical cord, alone is not an indication for caesarean section. Umbilical cord with 3 loops was associated with increased operative delivery and low Apgar score, proper intrapartum surveillance and portogram leads to good fetal outcome.
\end{abstract}

Keywords: Incidence of umbilical cord, Mode of delivery, Fetal outcome

\section{INTRODUCTION}

Incidence of umbilical cord around the neck ranges from lowest being 5 to $37 \% .^{1}$ Presence of umbilical cord around the neck is one of the common findings noted at the time of the delivery. Umbilical cord entangled about 360 degree around the neck is called the nuchal cord average length 50 to $55 \mathrm{~cm}$ and about $2 \mathrm{~cm}$ in diameter. ${ }^{2}$ Almost in many cases umbilical cord resolve during the time of delivery. ${ }^{3}$ Prevalence of umbilical cord is high as the gestation age increases (40-42 weeks).

The umbilical cord develops from and contains remnants of the yolk sac and allantois. ${ }^{4}$ It forms by the fifth week of development, replacing the yolk sac and become the primary source of nutrients. The cord is not directly connected to the mother's circulatory system, but instead joins the placenta, which transfers materials to and from the maternal blood without allowing direct mixing. The umbilical cord contains the Wharton's jelly, a gelatinous substance which is made up largely from mucopolysaccharides and this protects the blood vessels, it is derived from mesenchyme and embryonal stem cells. ${ }^{5,6}$

Causes of umbilical cord around the neck are excessive foetal movements, insufficient Wharton's jelly, excessive amniotic fluid in the sac, length of the cord and multifetal gestation. 
In the present study, incidence of cord around and its effects on various modes of delivery and fetal outcomes are studied.

\section{METHODS}

This study was conducted in Chettinad health city and research center, Kelambakkam over a period of 6 month (Feb-July 2020). Out of 540 total deliveries, during this period, patient was enrolled in this study as per the inclusion and exclusion criteria. This is a retrospective observational study.

\section{Inclusion criteria}

Inclusion criteria included singleton gestation, cephalic presentation and previous NVD.

\section{Exclusion criteria}

Exclusion criteria excluded multiple gestations, previous LSCS, patient undergoing elective LSCS, IUFD (intrauterine fetal death).

After this Inclusion and exclusion criteria, patient enrolled in the study, were divided into 2 groups.

Study group: Delivery with umbilical cord around the neck.

Control group: Delivery without umbilical cord around the neck.

\section{Selection of the patient}

Total delivery during the study period: 540 , total no of cases: 388 and number of patients delivered with umbilical cord around the neck:101.

\section{Outcomes studied}

Following outcomes were studied between these two groups are mode of delivery, number of LSCS, Apgar score less than 7 in $1^{\text {st }}$ min and $5^{\text {th }}$ min, NICU admission, length of the cord. Meconium staining of liquor and fetal distress and all the above data are entered using the SPPS software version 2.0.

\section{RESULTS}

Out of 388 cases, 101 patients $(38.4 \%)$ cases were found to have cord around the neck. In these 101 cases, 66 cases (65\%) had normal vaginal delivery, 27 cases $(26 \%)$ had caesarean section, and around $8 \%$ of the patients had instrumental delivery. The indication for caesarean section was fetal distress and Meconium-stained liquor.

In this study, most of the cases were in the age group of 21-25 at around (55\%) (Table 1).
Out of 101 patients with cord around the neck, around $73 \%$ were primigravida and $28 \%$ patients were multigravida.

Mean length of the cord in patients with cord around the neck is higher than the patient without cord around the neck and it is statistically significant $(\mathrm{p}=0.01)$.

Out of 388 cases, 101 cases had cord around the neck, in which the incidence of single loop was high and statistically significant $(63 \%)$. whereas double loop was $31 \%$ and triple loop was $7 \%$.

Table 1: Distribution of patients according to mode of delivery.

\begin{tabular}{|c|c|c|c|c|c|}
\hline MOD & $\begin{array}{l}\text { With } \\
\text { cord }\end{array}$ & $\begin{array}{l}\text { Without } \\
\text { cord }\end{array}$ & Total & $\begin{array}{l}\text { Chi } \\
\text { sq. }\end{array}$ & $\mathbf{P}$ \\
\hline Normal & 66 & 192 & 258 & \multirow{4}{*}{0.009} & \multirow{4}{*}{0.9} \\
\hline Instrumental & 8 & 11 & 19 & & \\
\hline LSCS & 27 & 84 & 111 & & \\
\hline Total & 101 & 287 & 388 & & \\
\hline
\end{tabular}

Table 2: Age distribution.

\begin{tabular}{|c|c|c|c|c|c|}
\hline $\begin{array}{l}\text { Age } \\
\text { (years) }\end{array}$ & $\begin{array}{l}\text { With } \\
\text { cord }\end{array}$ & $\begin{array}{l}\text { Without } \\
\text { cord }\end{array}$ & Total & $\begin{array}{l}\text { Chi } \\
\text { sq. }\end{array}$ & $\mathbf{P}$ \\
\hline$<20$ & 11 & 22 & 33 & \multirow{6}{*}{2.02} & \multirow{6}{*}{0.2} \\
\hline $21-25$ & 55 & 147 & 202 & & \\
\hline $26-30$ & 24 & 76 & 100 & & \\
\hline 31-35 & 8 & 28 & 36 & & \\
\hline $36-40$ & 3 & 14 & 17 & & \\
\hline Total & 101 & 287 & 388 & & \\
\hline
\end{tabular}

Table 3: Distribution of patients according to parity and cord around the neck.

\begin{tabular}{|c|c|c|c|c|c|}
\hline Parity & $\begin{array}{l}\text { With } \\
\text { cord }\end{array}$ & $\begin{array}{l}\text { Without } \\
\text { cord }\end{array}$ & Total & $\begin{array}{l}\text { Chi } \\
\text { sq }\end{array}$ & $\mathbf{P}$ \\
\hline Primi & 73 & 155 & 228 & \multirow{3}{*}{10.29} & \multirow{3}{*}{0.00} \\
\hline Multi & 28 & 132 & 160 & & \\
\hline Total & 101 & 287 & 388 & & \\
\hline
\end{tabular}

Table 4: Comparison of length of cord in both groups.

\begin{tabular}{|ll|ll|}
\hline Length & $\begin{array}{l}\text { With } \\
\text { cord }\end{array}$ & $\begin{array}{l}\text { Without } \\
\text { cord }\end{array}$ & P \\
\hline $\begin{array}{l}\text { Mean length of } \\
\text { cord (cm) }\end{array}$ & 45.39 & 44.64 & 0.01 \\
\hline
\end{tabular}

Table 5: Distribution of both the groups according to Apgar score and NICU stay.

\begin{tabular}{|lllll|}
\hline APGAR & $\begin{array}{l}\text { With cord } \\
(\mathbf{n = 1 0 1})\end{array}$ & $\begin{array}{l}\text { Without cord } \\
(\mathbf{n}=\mathbf{2 8 7})\end{array}$ & $\mathbf{Z}$ & $\mathbf{P}$ \\
\hline <7 in 1 $\mathbf{~ m i n}$ & 7 & 10 & 2.12 & 0.1 \\
\hline <7 in 5 $\mathbf{~ m i n}$ & 3 & 5 & 0.56 & 0.5 \\
\hline NICU & 25 & 50 & 2.57 & 0.1 \\
\hline MSL & 21 & 46 & 1.19 & 0.3 \\
\hline
\end{tabular}


Table 6: Number of loops at the time of delivery.

\begin{tabular}{|c|c|c|c|c|c|}
\hline $\begin{array}{l}\text { No of } \\
\text { loops }\end{array}$ & $\begin{array}{l}\text { With } \\
\text { cord }\end{array}$ & $\begin{array}{l}\text { Without } \\
\text { cord }\end{array}$ & Total & $\begin{array}{l}\text { Chi } \\
\text { sq. }\end{array}$ & $\mathbf{P}$ \\
\hline I & 17 & 46 & 63 & \multirow{4}{*}{21.56} & \multirow{4}{*}{0.0001} \\
\hline II & 23 & 8 & 31 & & \\
\hline III & 6 & 1 & 7 & & \\
\hline Total & 101 & 55 & 101 & & \\
\hline
\end{tabular}

Table 7: Incidence of cord around the neck.

\begin{tabular}{|ll|}
\hline Studies & Incidence (\%) \\
\hline Sheiner et al & 14.70 \\
\hline Pregrine et al & 18 \\
\hline Mastro Battista et al & 17 \\
\hline Present study & 38 \\
\hline
\end{tabular}

\section{DISCUSSION}

Crawford in 1962 first defined nuchal cord as the condition in which umbilical cord was coiled at least once around the neck of the fetus. ${ }^{7}$ Baden in 1955 wrote: "Intrauterine life, which is sustained only by two small arteries and a tortuous vein course through a long flexible cord, hangs by very delicate thread."11 Umbilical cord is the structures which provide the adequate nutrition and provide the gaseous exchange in the fetus. Pathophysiology of the umbilical cord around the neck causes the foetal arterial resistance and increases the blood pressure leading on to fetal bradycardia and decrease in cardiac output.

Excessive fetal movement and length of the cord increase the incidence of umbilical cord around the neck. Many studies show, around 20-50\% of umbilical cords mostly resolve before the delivery. Incidence is high in postdated pregnancies. $^{8}$ Dhar et al has found that the incidence of LSCS was $27.2 \%$ with tight cord and $15.7 \%$ with loose loop of umbilical cord. ${ }^{9}$ The present study showed no perinatal mortality associated with umbilical cord which is similar to studies done by Larson and Miser et al. ${ }^{10,11}$ Incidence of umbilical cord in our study is $38.4 \%$. Most of them are in the age group between 21-25 years.

In the current study number of loops in the cord varies from 1 to 3. Prevalence of 2 or more loops is reported at about 2.5 to $8.3 \%$. And $0.1 \%$ shows more than 3 loops and highest reported being 9 loops.

Kitagawa et al, in 1989 used analysis of umbilical cord gases and found positive relation of variable deceleration and low Apgar score and significant respiratory acidosis in cases with nuchal cord. ${ }^{12}$ In this study, its association with Apgar score and Meconium-stained liquor were seen. Such patients are to be closely monitored by CTG as the cord around the neck is associated with deceleration during labour. ${ }^{14,15}$
Other studies like Walker et al, found male babies had longer cord than female babies and it was assumed due to higher level of intrauterine activities of male fetus. ${ }^{13}$ Present study also observed that the proportion of males were significantly more than female among the neonates born with umbilical cord around the neck, but was not significant.

\section{Limitations}

The factors such as true knot, cord around the trunk and limbs found to interrupt the results of the study.

\section{CONCLUSION}

According to our study, the incidence of umbilical cord around the neck is $38.4 \%$. Identification of umbilical cord at the time of delivery is not an indication for caesarean section. Such patients are to be closely monitored by CTG. Multi centric approach during the labour aids in better perinatal outcomes and decreases caesarean section and instrumental delivery. This study clearly shows that there is no change in the mode of delivery when there is umbilical cord around the neck.

Funding: No funding sources Conflict of interest: None declared

Ethical approval: The study was approved by the Institutional Ethics Committee

\section{REFERENCES}

1. Singer DB, Macpherson T. Fetal death and macerated stillborn fetus. In: Wigglesworth JS, Singer DB, editors. Textbook of Fetal and Perinatal Pathology. Boston: Blackwell Scientific Publication. 1991;1:266-7.

2. Fetus or Newborn Problems. Labor and Delivery Complications: Merck Manual Home Edition. 2010.

3. Peregrine E, O'Brien P, Jauniaux E. Ultrasound Detection of Nuchal Cord Prior to Labor Induction and the Risk of Cesarean Section. Ultrasound Obstet Gynecol. 2005;25(2):160-4.

4. Meyer WW, Rumpelt HJ, Yao AC, Lind J. Structure and closure mechanism of the human umbilical artery. Eur J Pediatr. 1978;128(4):247-59.

5. Fetal Circulation. Available from: www.heart.org. accessed on 22 December 2017.

6. Saleh, R; Reza, HM. Short review on human umbilical cord lining epithelial cells and their potential clinical applications. Stem cell res therapy. 2017;8(1).

7. Crawford JS. Cord around the neck a further analysis of medicine. Acta Pediatrics. 1964;53:535-7.

8. Collins JH, Collins CL, Weckworth SR, Angelis L. Nuchal cords; timing of perinatal diagnosis and duration. Am J Obstet Gynecol. 1995;173:768.

9. Dhar KK, Ray SN, Dhall GI. Significance of nuchal cord. J Indian Med Assoc. 1995;93(12):451-3. 
10. Janet D, Larson MD, William F, Rayburn MD, Crosby RSS, Gary R et al. Multiple cord entanglement and intrrapartum complications. Am J Obstect Gynecol. 1995;173:1228-31.

11. Miser WF. Outcome of infants born with nuchal cords. Family practice service, Reynolds Army Community Hospital. Fortsill, UK. J Fam Pract. 1992;34(4): 441-5.

12. Bashir F, Huma Z, Aslam P. Cord around the neck and its Fetal outcomes. J Soc Obstet Gynaecol Pak. 2017;7(3):133-6.

13. Schaffer L, Burkhardt $T$, Zimmermann R, Kurmanavicious J. Nuchal cords in term and post term deliveries- Do we need to know? Obstet Gynecol. 2005;106:23-8.
14. Kasturi D, Marathe S, Manjunath N. A casecontrol study on perinatal outcome in neonates with cord around the neck in a tertiary care hospital, Hubli, Karnataka. Int J Reprod Contracept Obstet Gynecol. 2014;3(1):105-8.

15. Begum AA, Sultana H, Hasan R, Ahmed M. A Clinical Study of Fetal Outcome in Cases of Nuchal Cord. JAFMC Bangladesh. 2011;7(1);25-7.

Cite this article as: Nandhini $S$, Anuradha CR, Renuka S, Vijayalakshmi K, Sailatha R. Incidence of umbilical cord around the neck and its effects on mode of delivery and fetal outcome at tertiary care hospital. Int J Reprod Contracept Obstet Gynecol 2021;10:516-9. 